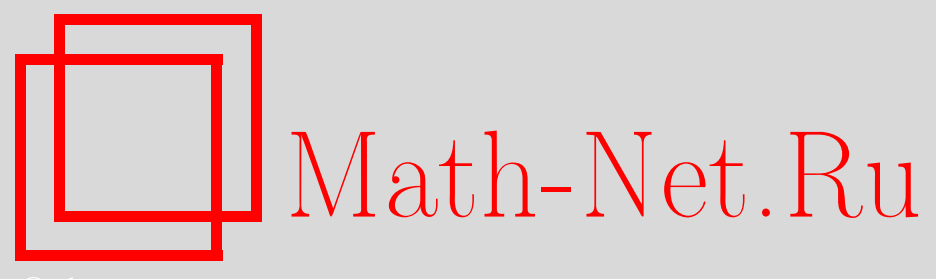

Л. Белопухов, Различные календари. Старый и новый стили, Квант, 2020, номер 3, 2-9

DOI: https://doi.org/10.4213/kvant20200301

Использование Общероссийского математического портала Math-Net.Ru подразумевает, что вы прочитали и согласны с пользовательским соглашением http://www.mathnet.ru/rus/agreement

Параметры загрузки:

IP : 35.173 .137 .237

26 апреля 2023 г., 03:00:32 


\section{Различные календари. Старый и новый стили}

\section{Л.БЕЛОПУХОВ}

B ПРЕДЫДУЩЕМ НОМЕРЕ ЖУРнала в статье «Календарь и астрономия» отмечалось, что древние календари были лунные, лунно-солнечные и солнечные. Наиболее древними считаются лунные календари, например календарь Китая и некоторых других соседних государств,

\section{Календари Китая}

Издавна в Китае было принято делить месяц на три декады, в каждой из которых было пять периодов по двое суток, которые носили названия «небесных ветвей» воды, огня, металла, дерева и камня. А годичный цикл подразделялся на 12 «земных ветвей», названных именами созвездий-животных: мышь, крыса, тигр, заяц, дракон, змея, конь, овца, обезьяна, курица, собака, свинья. Мы не знаем, выбор этих созвездий был произволен или всетаки как-то связан с движением Солнца по эклиптике.

Очевидно, что двенадцать 30-суточных циклов на 5 или 6 суток короче солнечного цикла повторения времен года. По этой причине за 15 лет происходил сдвиг на целый сезон. Как решалась эта проблема в древности, неизвестно. Но не так давно в Китае были обнаружены кости животных и панцири черепах, на которых сохранились письменные знаки о календаре эпохи ШаньИнь (18-12 в. до н. э.). Знаки свидетельствовали о том, что календарь в эту эпоху был не лунным, а лунно-солнечным, в котором лунные месячные циклы уже были как-то связаны с солнечным годом.

По многим источникам историки считают, что реформа календаря была проведе-

DOI: https://doi.org/10.4213/kvant20200301 на еще в середине третьего тысячелетия до нашей эры. Древние хроники свидетельствуют, что в 12 веке до нашей эры в Китае была построена специальная башня для астрономических наблюдений. Тщательно фиксировались перемещения Луны и Солнца по небесному своду. Многолетние записи этих наблюдений позволили древнекитайским астрономам предсказывать лунные и солнечные затмения. Это считалось важным государственным делом (однажды за неправильные предсказания два астронома были даже преданы суду и казнены).

Но главной задачей астрономов было уточнение лунно-солнечного календаря. При переходе на этот календарь сформировавшиеся названия суток и месяцев, как земных и небесных ветвей, были перенесены на солнечные циклы - годы. Древнекитайские астрономы смогли определить, что примерно за 60 лет полностью повторяется цикличность смены времен года на протяжении годичного календаря. Появилась крупная календарная единица - 60 лет. Это и был древнейший в мире лунно-солнечный календарь. В Китае он оставался государственным календарем вплоть до 1912 года, когда его сменил календарь европейских стран. Но до сих пор половина средств массовой информации в Китае наряду с государственным европейским использует и свой старинный лунно-солнечный календарь. Да и в европейских странах есть «мода» на этот календарь, в котором каждый год имеет одно из 12 основных названий земных ветвей с подразделениями по 5 небесным ветвям. Внутри 60-летнего цикла начало каждого года перемещается в течение первых трех месяцев.

Прошлый китайский год земляной (каменной) свиньи начался 5 февраля 


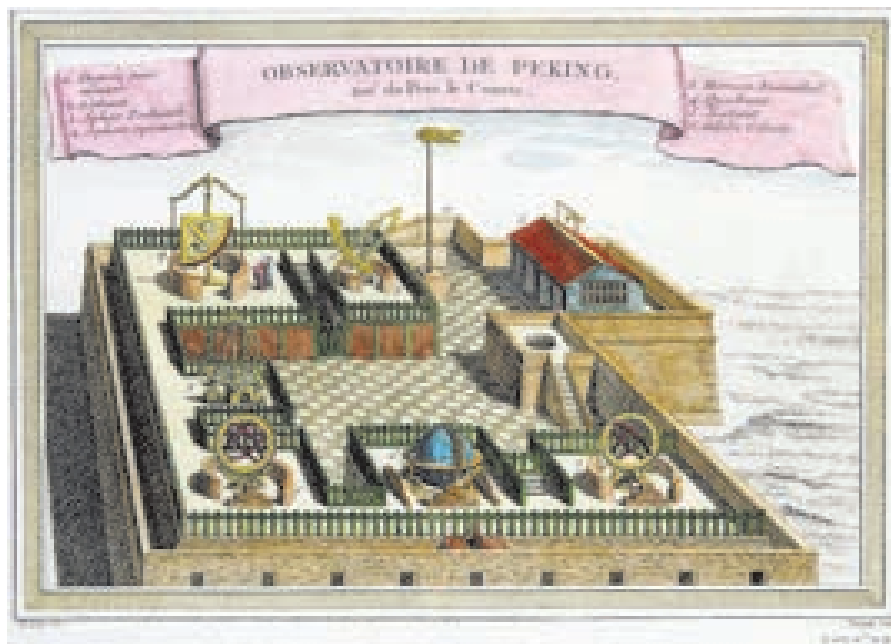

Астрономическая обсерватория в Пекине (1154г.)

календарю. Мухаммед выбросил из истории все астрономические достижения и вернул древний календарь: «...ибо Аллах сотворил год продолжительностью в 360 дней и исключил из него шесть дней, в которые он создал небо и землю, так что этих дней нет в счете. Вставка 13-го месяца - это увеличение неверия, ибо понятное число месяцев - 12». И сейчас весь мусульманский мир, а это почти полтора миллиарда человек, живет по лунному календарю, несмотря на его неточность и неудобство.

В странах, не контактировавших с государствами Передней

2019 года по нашему календарю. А текущий год стал годом металлической (белой) крысы, и начался он 25 января 2020 года. Правда, в основном европейцы полюбили названия только земных ветвей (животных), да и то, наверное, потому, что они иллюстрируются огромным ассортиментом сувенирной продукции.

\section{Другие древние календари}

Лунно-солнечный календарь действовал во многих древних государствах Ближнего Востока. Характерным его признаком стала вставка добавочного месяца в определенные моменты года. В старо-вавилонском государстве это делалось по распоряжению властей (приложения к законам Хаммурапи). Но с развитием астрономических наблюдений возникли определенные правила для этих вставок. При этом день весеннего равноденствия связывался с положением Солнца на эклиптике. Лунно-солнечный календарь использовался во всех государствах Месопотамии, в древне-еврейском государстве и в Древней Греции. И сейчас государственным календарем Израиля является лунно-солнечный календарь.

До возникновения ислама (седьмой век нашей эры) лунно-солнечный календарь действовал и в Аравии. Но страны ислама по завету его создателя Мухаммеда (571632 гг. нашей эры) вернулись к лунному
Азии либо по географическим причинам, либо по причине закрытости культуры, еще в глубокой древности возникли солнечные календари. Это относилось к центрально- и южно-американским государствам, а затем и к Древнему Египту. У майя и ацтеков календарные системы были очень сложными с многими единицами времени, отражавшими сельскохозяйственные работы и религиозные установления. Найдено больше 300 развалин пирамидальных башен и других древних сооружений, стены которых использовались для нанесения знаков, в том числе и связанных с календарем. Но язык этих народов с трудом поддается расшифровке. Интересно, что значительный вклад в понимание календаря майя сделал знаменитый американский физик Ричард Фейнман - это было одним из его хобби.

Календарь египтян Древнего царства, эпохи гигантских пирамид, был лунным. Но в эпоху Нового царства, во втором тысячелетии до нашей эры, египетские жрецы сумели создать солнечный календарь, осложненный ежегодным восходом яркой звезды Сириус в определенный день июля, совпадающий с началом бурного разлива Нила, главного достояния страны. По типу этого календаря в первом столетии до нашей эры в эллинистическом Египте астрономом Созигеном был создан так называемый александрийский кален- 
дарь, который и стал основой современных календарей. По этому календарю длительность года была принята в 365 суток, а раз в 4 года - в 366 суток. Таким образом, средняя продолжительность года в сутках была принята как 365,25 - так называемый календарный год. В году было 12 месяцев по 30 дней, а после 12-го месяца - 5 (или раз в три года 6) дополнительных суточных вставок. Такими были и древнегрузинский и древне-армянский календари. Сейчас александрийским календарем пользуются только копты - прямые потомки древних египтян, принявшие христианство с 284 года. Копты - это значительная часть современного египетского населения (около 10\%). В Египте и его столице они живут компактно, образуя как бы анклавы внутри страны, сохраняя язык и свои древние обычаи такими, какими они были в третьем веке нашей эры.

Любопытно, что солнечный календарь александрийского типа существовал во Франции во время Великой французской революции, пока Франция была республикой (1789-1799), и в короткий период Парижской коммуны (18 марта - 28 мая 1871 г.). Названия месяцев этого календаря полностью отражали сезонные изменения в погоде и в сельскохозяйственном труде, например: брюмер - месяц тумана, термидор - месяц жары, жерминаль месяц посева, прорастания пшеницы, вандемьер - месяц сбора винограда. Каждый месяц делился на 3 декады, дни которых имели названия, состоящие из латинских слов: примиди - первый день, дуоди второй день и т.д. Очень стройная и привлекательная календарная система! Добавочные дни имели романтические названия - праздник Гения, праздник Подвига и др. Раз в 4 года один добавочный день посвящался спортивным играм и состязаниям. Оказывается, что еще за 100 лет до появления современного олимпийского движения во Франции вспомнили об олимпийских играх Древней Греции, происходивших раз в 4 года. Неслучайно и инициатором организации современных олимпиад стал француз - Пьер де Кубертен.

\section{Календарь Древнего Рима}

Календарь Римской республики (50927 до н.э.) был солнечным, но крайне запутанным. Римляне были очень суеверны и не любили четных чисел. Семь месяцев у них имели по 29 дней, четыре - по 31 дню, а в феврале было 28 дней. Этот месяц был назван в честь Фебрууса, этрусского бога подземного царства и римского бога очищения. В этом месяце справлялась поминальная неделя. Другие месяцы именовались либо в честь богов (Януса, Марса, Майи, Юноны), либо по номерам, начиная с пятого (квинтилис, секстилис, септембер, октобер, новембер, децембер). Исключение - априлис (раскрывающий, согреваемый Солнцем). Квинтилис (июль) был пятым по счету месяцем, поскольку год начинался с марта.

Очень сложно именовались в римском календаре дни. Недельные циклы отсутствовали. В каждом месяце было три особых дня. Все первые числа месяцев назывались календами, отсюда и слово «календарь». Седьмой день в длинных (по 31 дню) и пятый в остальных месяцах именовались нонами. А 15-е число в длинных месяцах и 13-е в остальных назывались идами. Дни перед этими числами были канунами (отсюда и наше русское «накануне»).

А остальные дни именовались очень странным образом - обратным включительным счетом. Например, 4 августа (короткого месяца, в котором ноны приходились на 5 число) называлось кануном августовских нон, 11 августа - третьим днем до августовских ид (приходящихся на 13 августа), а 23 августа - восьмым днем до сентябрьских календ. Интересно, что вторых дней до нон, ид и календ не существовало, они именовались канунами. Ну, а первыми днями (по включительному счету) были эти самые ноны, иды и календы.

Годовой подсчет дней древнеримского календаря дает 355 дней. Недостающие до солнечного года 10,25 суток требовали включения в календарь добавочных дней. И это мероприятие было запутано до предела. 
Например, после 23 февраля вставлялся добавочный месяц длительностью в 22 или 23 дня, а по его истечении снова продолжался февральский счет дней до мартовских календ. Месяц этот назывался мариедонием от латинского «расплата», поскольку в этом месяце производились все денежные расчеты за минувший год. Ноны и иды в марцедонии были, как в коротком месяце, а календы и вовсе отсутствовали.

Этот порядок действовал много сотен лет. Но в начале второго века до нашей эры римские жрецы, которые управляли календарем, стали манипулировать длительностью и временем вставки этого добавочного месяца. В Римской республике весь комплекс административных должностей - консулы (высшая должность), квесторы, цензоры и т.д. - был выборным сроком ровно на один год. А поскольку эти должности приносили определенный доход и другие жизненные преимущества, продление их срока было выгодным делом. Манипулируя календарем, жрецы могли увеличивать эти сроки в пользу того или иного должностного лица, наверняка небескорыстно. Могли иметь место и экономические причины изменения времени вставки в календарь месяца расплаты.

О конкретном грядущем календаре население республики оповещалось жрецами в конце февраля. Об этом запутанном древнеримском календаре через много лет Вольтер сказал: «Римские полководцы всегда побеждали, но они никогда не знали, в какой день это случилось».

\section{Юлианский календарь}

Его установил в 46 году до нашей эры своим указом римский диктатор и верховный жрец, полководец и государственный деятель Гай Юлий Цезарь (100-44 до н.э.).

Юлий Цезарь произвел реформу календаря, прежде всего опираясь на свои права верховного жреца. За основу он взял египетский (александрийский) солнечный календарь. Семь месяцев стали иметь длительность по 31 дню, четыре месяца - по 30 дней. А один месяц имел 28 дней, но раз в четыре года - 29 дней. В году стало 365 или, раз в четыре года, 366 дней. Это

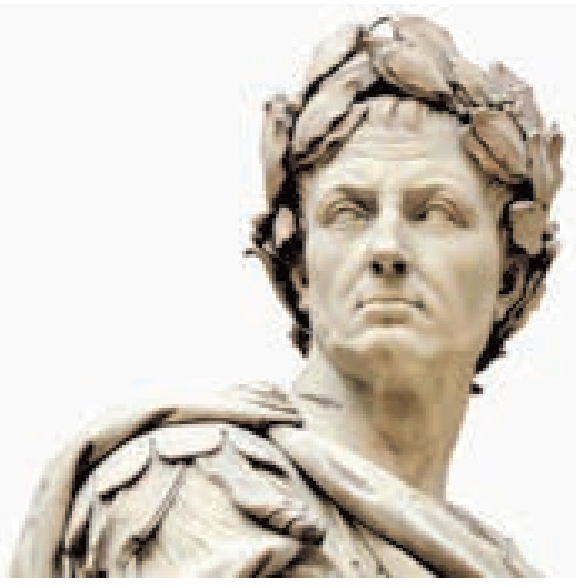

Гай Юлий Цезарь

соответствовало солнечному году в 365,25 суток. Добавочным днем раз в четыре года было не 29 февраля, как мы привыкли, а вставной день между 24 и 25 февраля, или по римскому календарю - между шестым и пятым днем до 1 марта. Он получил официальное название «дважды шестой до мартовских календ» - bis sectum Kal.Mart. Вот это самое bis sectum и превратилось для нас в слово високосный, а соответствующие годы стали впоследствии называться високосными годами. Начало года было перенесено Цезарем с 1 марта на 1 января.

Вот собственно и вся реформа. Ее четкость и простота так восхитили измученных своим календарем римлян, что в благодарность (в том числе и за военные заслуги) римский сенат переименовал месяц Квинтилис в Юлиус (в этом месяце родился Цезарь).

Через год, в мартовские иды 44 года до новой эры, Цезарь был убит заговорщиками во главе с Брутом. Началась борьба за власть между полководцами Антонием и Октавианом. Жрецы воспользовались неразберихой во власти и некоторое время продолжали «командовать» календарем по своему усмотрению, изменяя порядок високосных лет и вставку добавочного дня. И только через 50 лет юлианский солнечный календарь наконец заработал так, как это было задумано Цезарем. Это сделал полководец Октавиан, за военные и гражданские заслуги получивший от 


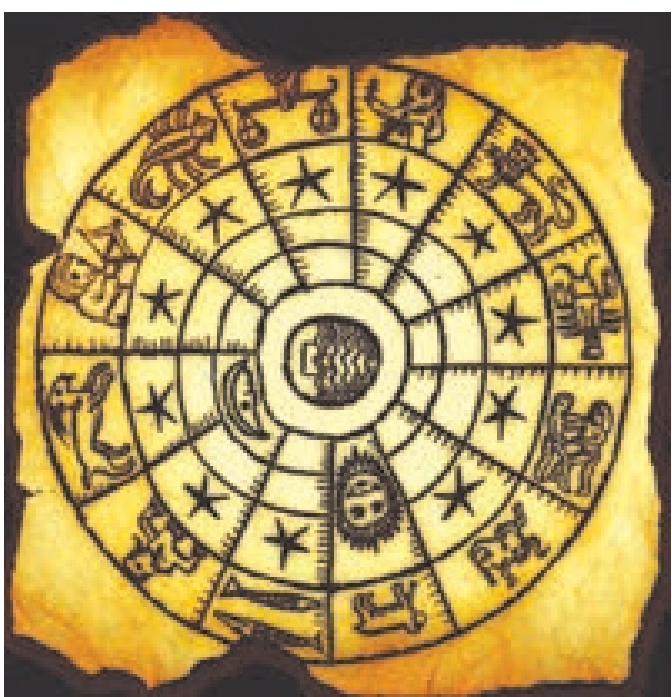

Юлианский календарь

сената пожизненный «империй» (чрезвычайные права, которые раньше давались полководцу на короткое время военных действий). Это означало фактическое превращение республики в империю. Октавиану сенат присвоил титул императора и имя Август («преумножающий»).

Август сделал юлианский календарь государственным, обязательным на всей огромной территории Римской империи с 1 января 4 года нашей эры. Месяц септилий был переименован в $а в г у с m$ и было подправлено чередование длинных и коротких месяцев - оно стало таким, как сейчас.

Юлианский календарь просуществовал во всей Европе (и Византии) до конца XVII века. А сейчас по нему живет только ортодоксальная (православная) христианская церковь.

\section{Необходимость изменения юлианского календаря}

Так зачем же нужно было заменять юлианский календарь? Причина этого - чисто арифметическая. Юлианский календарь основан на том, что период солнечного цикла, так называемый календарный год, составляет 365,25 суток. Но с календарем должен быть связан так называемый тропический год, длительность которого чутьчуть меньше - 365,2424 суток.

В первые века нашей эры, когда стал общепринятым юлианский календарь, казалось, что маленькая разность этих периодов несущественна и не мешает календарю. Как нетрудно определить, она приводит к сдвигу календаря на одни сутки за 128 лет. Когда постепенно исчезала власть Римской империи и потом, в «темные столетия» раннего Средневековья, этот сдвиг мало кого интересовал. Но в XVI веке, в эпоху «осени Средневековья», которую чаще называют эпохой Возрождения, человеческий быт и общественное сознание так изменились, что многие общественные деятели и ученые стали выражать беспокойство по поводу неточности календаря.

В христианском европейском мире документальным началом отсчета считается четвертый век нашей эры, когда указом римского императора Константина христианство стало государственной религией. За прошедшие после этого 12 веков сдвиг юлианского календаря составил уже больше 9 дней. Одной из причин беспокойства стало перемещение дня весеннего равноденствия с 21 марта на 12 марта. А с этим днем было связано начало многих сельскохозяйственных работ, и время подготовки к ним существенно сократилось. Весна по календарю наступала все раньше и раньше.

Но была и еще одна причина беспокойства. Она имела религиозное обоснование. В христианских общинах Римской империи к началу IV века установился обычай отмечать как самый светлый праздник ставшую легендарной дату воскресения Христа. События, связанные с казнью Христа, происходили в Иерусалиме, столице римской провинции Иудеи, в дни, являвшиеся важным иудейским праздником, называвшимся «песах». Начиная с 12 века до нашей эры в иудейской религии этот праздник отмечался как память о благополучном исходе евреев из Египта, где они считались низшей расой.

В начале нашей эры (как, впрочем, и сейчас) в Иудее продолжал действовать лунно-солнечный календарь, согласно которому весенний месяц Нисана перемещается относительно природного календаря, например относительно дня весеннего рав- 
ноденствия. К последним дням песаха приурочивались и казни преступников, как праздничное «развлечение» для народа. На основании устных преданий и, повидимому, не дошедших до нашего времени письменных свидетельств, четыре античных историка зафиксировали, что казнь Христа произошла 13 Нисана, а его воскресение - 15 Нисана 30-го года нашей эры.

В ранних христианских общинах и установился обычай ежегодно отмечать 15 Нисана еврейского календаря как праздник Светлого Воскресения. Почти во всех европейских языках этот день получил название «пасха», очень похожее на еврейское «песах».

Естественно, что еврейское 15 Нисана в юлианском календаре приходилось на разные дни. В уточняющих эту дату устных преданиях говорилось о том, что это было после дня весеннего равноденствия и первого после этого полнолуния. И в 325 году первый христианский собор (съезд всех епископов - руководителей христианских общин империи), организованный императором Константином в городе Никея и поэтому получивший имя Никейского собора, установил каноном празднование Пасхи в первое воскресенье после первого новолуния после весеннего равноденствия. По юлианскому календарю разброс дня Пасхи составил 36 дней - с 20 марта по 25 апреля. Соответственно перемещались по календарю и все связанные с Пасхой религиозные дни и установления - весенние и летние посты, день Святого Духа, Троицын день и др. Недаром они называются переходящими в отличие от постоянных в календаре (Рождество Христово, осенний пост, Благовещение и пр.).

Но когда реальные астрономические события, и прежде всего весеннее равноденствие, стали заметно (на 10 дней) не совпадать с каноном празднования Пасхи по юлианскому календарю, необходимость календарной реформы стала неотвратимой.

\section{Григорианский календарь}

Проблема календарной реформы обсуждалась католической церковью на несколь- ких соборах. На последнем из них был рассмотрен проект изменения календаря, подготовленный итальянским врачом и астрономом Луиджи Лилио. Суть проекта была достаточно простой. Луиджи Лилио (лат. Алоизий Лилий) не использовал аппарат «цепных дробей» (см. статью «Календарь и астрономия»), он просто подобрал в качестве добавки к 365 суткам не 1/4, а 97/400. Таким образом, за 400 лет число високосных лет должно быть равно не 100, как в юлианском календаре, а 97. Период в 400 лет был выбран Луиджи Лилио без всякого математического или астрономического обоснования, а из соображений удобства введения нового календаря. Для того чтобы согласие календаря с астрономическим годом стало хорошим, достаточно было каждые 400 лет убирать трое суток из 100 високосных лет. Нужно было лишь договориться, какие три високосных года станут простыми (без 29 февраля). Логичным было предложение взять те годы, две первых цифры которых не кратны четырем. Например, 1600 год в проекте реформы оставался високосным, как и 1604, 1608,.., 1696, а вот 1700 год уже не должен быть високосным. Это же относится к 1800 и 1900 годам. А 2000 год опять станет високосным. И для того чтобы «выровнять» календарь с астрономическим временем, необходимо было в какой-то момент «убрать» из календаря 10 дней. Это-то и было самым трудным в реформе для ее понимания простыми людьми. Да и не только простыми.

Для внедрения реформы во всем христианском мире нужен был авторитет выше авторитетов властителей отдельных государств. Таким авторитетом в 1570-е годы обладал только римский папа - глава католической конфессии христианства. Но несмотря на одобрение собором проекта реформы, в течение 14 лет папы Пий IV и Пий $\mathrm{V}$ не решились на активные действия. И только Григорий XIII (римский папа с 1572 по 1583 год), да и то не сразу после избрания, а за месяц до своей кончины 24 февраля 1582 года, издал постановление (буллу), озаглавленное «Среди важнейших» («Inter gravissimas»). Вот выдержки 


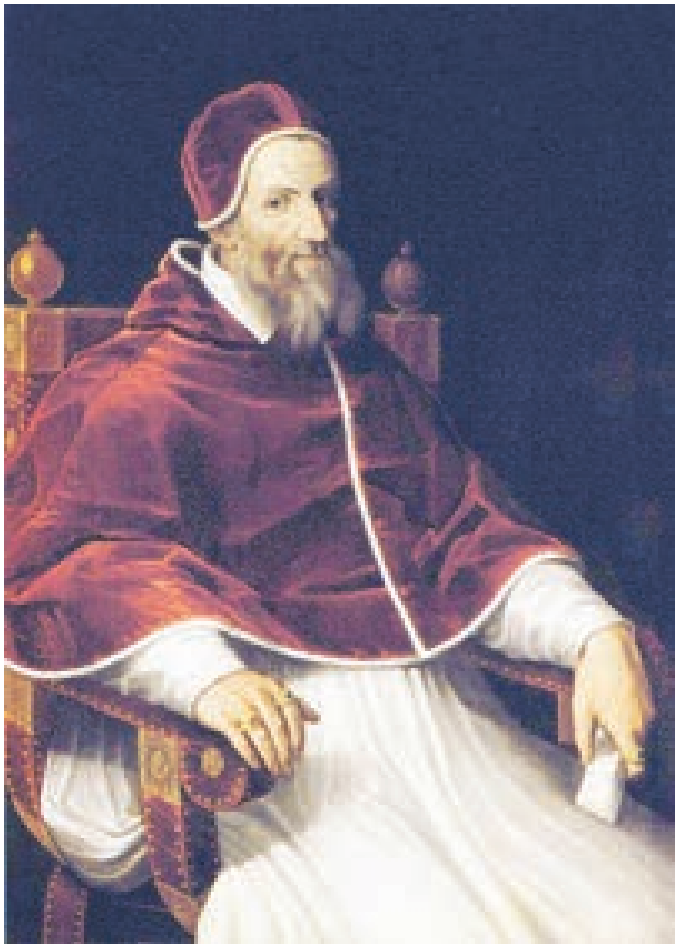

Григорий XIII

из него:

«Было заботою нашей не только восстановить равноденствие на издревле назначенном ему месте, от которого со времени Никейского собора оно отступило на десять дней приблизительно, и полнолунию вернуть его место, но и установить также способ и правило, которым и будет достигнуто, чтобы в будущем равноденствие и полная луна со своих мест никогда не сдвигались...

А посему мы предписываем и повелеваем касательно месяца октября текущего 1582 года, чтобы десять дней от третьего дня перед нонами (5 октября) до кануна ид (14 октября) включительно были изъяты».

Помимо этого был приведен в порядок и 19-летний цикл смен лунных фаз, чтобы можно было день пасхи рассчитывать заранее. Одновременно начал происходить и переход к современному счету дней от первого до последнего дня месяца.

Новая календарная система получила название григорианской, или нового сти- ля (н.ст.). А за юлианским календарем закрепилось название старый стиль (cm.cm.). В конце XVI века различие датировок событий по старому и новому стилям составляло 10 дней. Таким же оно осталось и в XVII веке, поскольку 1600 год был високосным и в старом (юлианском) и в новом (григорианском) календаре. Но уже в XVIII веке различие составляло уже 11 дней, поскольку 1700 год был в юлианском календаре високосным, а в новом календаре он високосным не был (17 не делится на 4 без остатка). По такой же причине в XIX веке разница между старым стилем и новым составляла 12 дней, а в XX веке - 13 дней. В нашем XXI веке различие по-прежнему составляет 13 дней, поскольку 2000 год был високосным в обоих календарях, но в XXII веке различие увеличится уже до 14 дней.

Григорианский календарь заметно более точен, чем юлианский. Его среднегодовая погрешность составляет всего лишь 30 секунд. Если по юлианскому календарю сдвиг весеннего равноденствия на 1 сутки происходит за 128 лет, то по григорианскому календарю такой сдвиг произойдет за 2800 лет! У григорианского календаря есть и недостатки. В частности, из-за неравномерного распределения в 400-летнем периоде трех «убранных» високосных лет дни равноденствий перемещаются по ка-

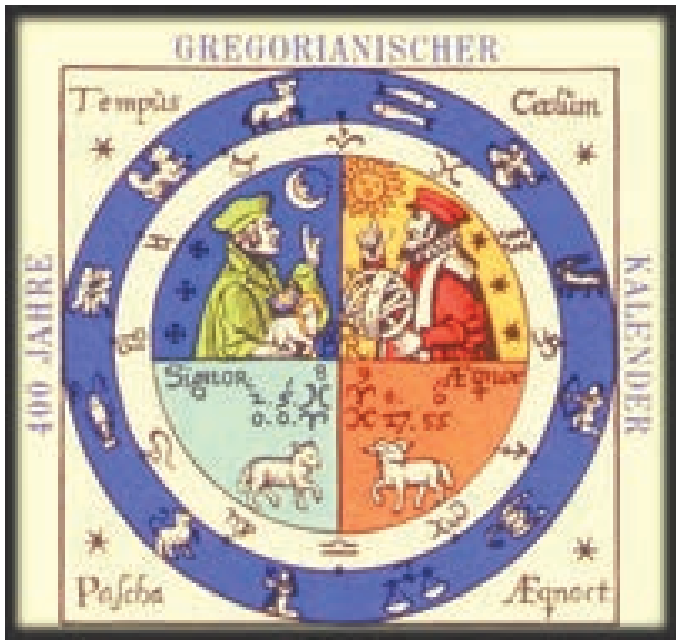

Григорианский календарь 
лендарю в пределах двух-трех суток.

И вполне возможно, что уже в нынешнем столетии будет создан и внедрен другой календарь, такой же точный и в то же время более удобный. Таких проектов много, есть даже комиссия ООН, которая должна заниматься этой проблемой.

\section{Внедрение нового стиля}

Как происходило внедрение григорианского календаря? В католических странах реформа 1582 года была принята практически сразу (из-за угрозы отлучения от церкви в случае непослушания). Но в протестантских странах она вызвала бурю протестов и ожесточенную полемику даже среди ученых. Особенно ретивыми в этом проявили себя немецкие, голландские и швейцарские протестанты, которые считали, что «лучше разойтись с Солнцем, чем сойтись с папой». В то же время самый знаменитый тогда немецкий астроном Иоганн Кеплер, хоть и был протестантом, выступил за реформу. Но к нему не прислушались, и внедрение реформы календаря в протестантских странах растянулось на несколько десятков лет. Дольше всего сопротивлялась Англия, что, в частности, до сих пор вызывает неопределенность с днем рождения великого Ньютона.

Православная церковь (Константинопольская, Антиохийская, Греческая, Болгарская, Русская и др.) отказалась принять григорианскую систему и некоторые новые правила определения дня пасхи, поэтому дни православной пасхи и католической могут разниться на неделю. По григорианскому календарю самое раннее празднование пасхи - 2 апреля, а самое позднее -8 мая. Для определения дня пасхи была еще до реформы календаря разработана система, в которой большую роль играл и 19-летний цикл календарного повторения лунных фаз. Было создано несколько арифметических систем с использованием специальных слов и обозначений. В 1800 году 23-летний будущий великий «король математиков» Карл Фридрих Гаусс предложил сравнительно про- стой алгоритм определения дня пасхи (его легко можно найти в интернете).

В Россию христианство пришло из Византии в конце IX века. Тогда христианская церковь была единой. Когда в XI веке произошел раскол христианства на две конфессии, Русь осталась верна византийской конфессии, которая получила название ортодоксальной (верной решениям только семи первых вселенских соборов). Сейчас в России эту конфессию христианства принято называть православной церковью. Россия сохранила верность старине и после государственного конца Византии в 1453 году. Поэтому в России не сразу состоялся переход к григорианскому календарю, тем более что католическая конфессия (церковь) христианства во главе с римскими папами была враждебна российскому государству.

До 1917 года церковь в России не была отделена от государства, но одним из первых указов новой власти был декрет об отделении церкви от государства. Имея в виду организацию мировой пролетарской революции, необходимым стал и переход на европейский григорианский календарь. Уже в ноябре 1917 года этот вопрос был поставлен на обсуждение Совнаркома, который и принял 24 января 1918 года «Декрет о введении в Российской республике западноевропейского календаря». В декрете говорилось: «В целях установления в России одинакового почти со всеми культурными народами исчисления времени Совет народных комиссаров постановляет ввести по истечении января месяца сего года в гражданский обиход новый календарь. Для этого первым днем после 31 января сего года считать не 1 февраля, а 14 февраля, вторым днем считать 15 февраля и т.д.» Заметьте, что новый календарь в декрете не был назван «григорианским», чтобы не возникал вопрос о том, что его внедрял римский папа.

Завершим эту тему словами американского астронома Г.Мойера: «Григорианский календарь представлял собою весьма удовлетворительный компромисс между необходимой точностью и крайне желательной простотой». 